\title{
Sea Surface Temperature and Wind Velocity in Batam Waters Its Relation to Indian Ocean Dipole (IOD)
}

\author{
Muhammad Zainuddin Lubis ${ }^{1} *$, Wenang Anurogo ${ }^{1}$, Husnul Kausarian ${ }^{2}$, \\ Ganda Surya ${ }^{1}$, Tiggi Choanji ${ }^{2}$ \\ ${ }^{1}$ Department of Informatics Engineering, Geomatics Engineering, Politeknik Negeri Batam, Batam Kepulauan Riau, 29461 Indonesia.
} Department of Geological Engineering, J. Kaharuddin Nasution No 113, Universitas Islam Riau, 28125, Indonesia.

* Corresponding author : zainuddinlubis@polibatam.ac.id

Tel+6281342578087, Office : 778-469856 ext : 2510; fax: $+62-778-463620$

Received: Oct 18, 2017. Revised: Nov 19, 2017, Accepted: Nov 30, 2017, Published: 1 Dec 2017

DOI : 10.24273/jgeet.2017.2.4.778

\begin{abstract}
This study aimed to observe the characteristics of sea surface temperature (SST) and wind velocity and its relation with the Indian Ocean Dipole (IOD) in the waters of Batam. The data used in this study were the SST datasets and the wind speed of 2016 in the waters of Batam. The method used in this research were the visual analysis using the data ocean view (ODV) to observe at the spatial and temporal distribution of the SST and the wind speed in Batam waters at different seasons. The next method is a fast Fourier transform (FFT). The earlier monsoon season that occurred in April has the highest wind speed with the value of $3.9 \mathrm{MS}^{* *^{-1}}$ for components $\mathrm{U}$. As for the $\mathrm{V}$, the component has the highest value of $-3.6 \mathrm{MS}^{* *-1}$. The SST Batam observed high in April occurred on 19-04-2016 with a value of $304.2^{\circ} \mathrm{K}\left(31.05^{\circ} \mathrm{C}\right)$. West monsoon winds that occurred in January has the highest wind speed with a value of $4.5 \mathrm{MS}^{* *-1}$ for components $\mathrm{U}$. As for the $\mathrm{V}$, the component has the highest value of $5.2 \mathrm{MS}^{* *^{-1}}$ in the waters of Batam. The highest SST in Batam occurred in January on 19-01-2016 with a value of $302.8^{\circ} \mathrm{K}\left(29.65^{\circ} \mathrm{C}\right)$. Based on the results of the FFT, wind speed and SST in the waters of the Island has a dominant 6-month period (semiannual).
\end{abstract}

Keywords: SST, fast fourier transform (FFT), components U, components V.

\section{Introduction}

Indian Ocean Dipole (IOD) is identified as one of the leading modes of variability in tropical climates (Sahu et al., 2012). A positive IOD phenomenon (PIOD) is characterized by cooler water temperatures than usual that occur in the tropical eastern part of the Indian Ocean and warming up of ordinary water temperatures in the tropical western Indian Ocean (Manyilizu et al., 2016), and indicating the role of IOD when it weakens ENSOmonsoon relationship (Koch-Larrouy et al., 2008).

Indian Ocean Dipole (IOD) has just been categorized as one of the phenomena of the relationship between the ocean and the atmosphere in the tropical sector of the Indo-Pacific region. Thus, it can be explored the possible influence of Indian Ocean Dipole (IOD) on The Indian summer monsoon rainfall (ISMR) (Gadgil et al., 2004). It is observed that there is a remarkable Sea surface temperature effect in the equatorial Indian Ocean, and with the hypothesis that there is a Sea surface temperature effect arising from the dynamic interaction between the marine atmosphere in the Indian Ocean, the dynamics of the coast will affect Sea surface temperature variability in a waters (Ginzburg et al., 2008; Kausarian et al., 2016a; Kausarian et al., 2016b; Kausarian et al., 2017).
In fact, it is shown by the analysis of summer boreal composite anomalous observed sea surface temperature (SST) during strong IOD positive and negative years that there is a significant relationship of phase between the SST in the eastern and western tropical Indian Ocean for many years (Sahu et al., 2012).

El Nino and La Nina is a symptom that shows the global climate change that is affecting the climatic conditions in Indonesia. El Nino is an event of warming sea surface water temperature on the west coast of Indonesia (Gaol and Manurung, 2000). La Nina is the opposite of El Nino. The incident began when El Nino was weakened, and the hot ocean water on the coast of Peru came back cold again. Many IOD Events are shown to occur independently of El Nino (Kogan, 2000; Naylor et al., 2001).

\section{Material and Methodology}

Locations that are set for research are the water territories around Batam, with located between: 0o 25' 29 " N - 1o 15' 00" N - 1030 34' 35" E - 1040 26' 04 "E. The data used are monthly data, and annual data for 1 year is (January - December 2016) with time interval 06:00:00, 12:00:00 for 1 month (Fig. $1)$. 


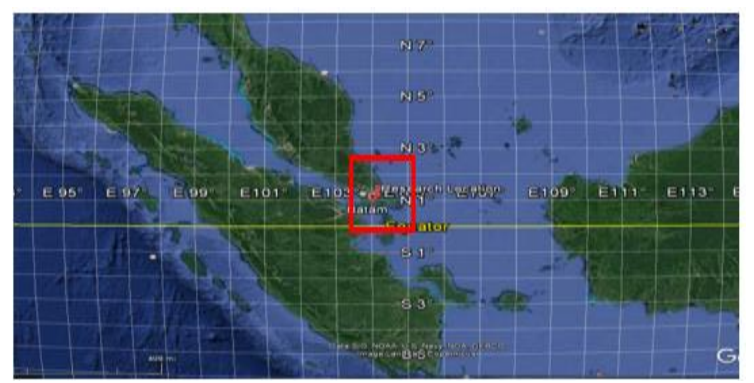

Fig. 1. Research location (waters area around Batam)

\section{Computer Assisted Data Collection Method (CADC)}

Data collection using computer-assisted data collection method is the method of taking data/information sourced from the internet. Data is sourced from ECMWF (http://www.ecmwf.int) with a grid format of $0.125 \times 0.125$. The data taken are wind speed data in the direction of the $x$-axis (eastwest), the $y$-axis direction (north-south), and sea surface temperature data (Sea Surface Temperature). From the uniform U-direction wind pressure data for 1 year is calculated using the relationship:

$\mathrm{T}=y^{2} \mathrm{p}^{\prime} \mathrm{U} 2$

$\mathrm{T}=y^{2} \mathrm{p}^{\prime} \mathrm{V} 2$

Where:
$y^{2}:$ The coefficient of resistance
$P$ ': Air volume
$\mathrm{U} / / \mathrm{V}$ : component velocity $10 \mathrm{~m}$ above sea level

At wind power 3 Beaufort or lowest sea level can be assumed as a fine hydrodynamic, with a barrier coefficient of about $0.8 \times 10^{-3}$, decreasing with increasing wind speed. At Beaufort Wind power 4 and higher constant value, $\mathrm{y}^{2}=2,6 \times 10^{-3}$, used, corresponds to the hydrodynamic rough surface (Rossby'0). All data will be processed using Ocean Data View (ODV) software, and MATLAB Software.

\section{Spatial Visual Method with Ocean Data View (ODV)}

ECMWF data is processed using ODV application, by making time series, temperature graph $(K)$, component graphs in the direction of the $\mathrm{U}$ axis $\left(\mathrm{MS}^{* *^{-1}}\right), \mathrm{X}\left(\mathrm{MS}^{* *^{-1}}\right)$ based on monthly time, and time series of temperature charts for a year. Import the ODV result data to MS.Excel to continue the creation of Fast Fourier Transform (FFT) method using MATLAB application.

\section{Fast Fourier Transform Method}

The basis for studying the frequency characteristics of a signal is the Fourier transform. Fast Fourier transform (FFT) is an algorithm for calculating Fourier transform. A signal at time domain, nominal, $x(t)$ ca is converted in a signal at the frequency domain, nominal $X(f)$. The algorithm of the FFT method as shown in the following equation. (Mudelsee, 2004). This in turn allows us to introduce the Fourier transform of the averaged autocovariance function of the modulated process, which is equal to its expected periodogram. Through examining the expected periodogram, the properties controlling the latent random process may be inferred even when the modulating function changes very rapidly. The standard class of modulated processes are asymptotically stationary modulated (Yang et al., 2014).

$$
\begin{aligned}
& X(f)=\int_{-\infty}^{\infty} x(t) \bullet e^{-2 s t} d t . \\
& x(t)=\int_{-\infty}^{\infty} X(f) \bullet e^{-2 \text { st }} d f .
\end{aligned}
$$

PSD is a variation of electricity (energy) as a function of the frequency spectrum in the form of estimated density using FFT, the PSD method is one of the modern spectral estimation techniques proposed during this decade (Mudelsee, 2004). The research flow diagram can be seen in Fig. 2.

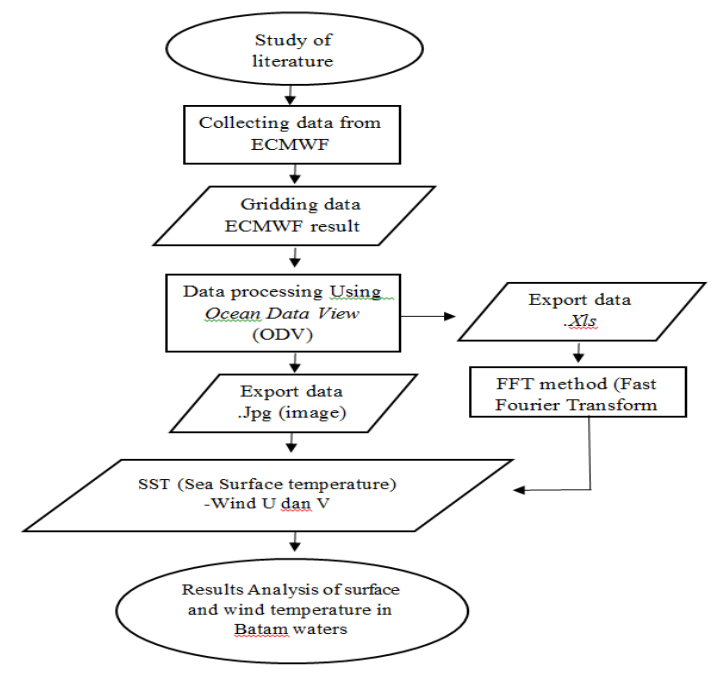

Fig 2. Flowchart of research

\section{Results And Discussion}

Batam is one of the tropical cities located in Riau Islands province (0o 25' 29 " N - 1o 15' 00" N - 1030 34' 35" E - 1040 26' 04" E) which has an area of $2,950 \mathrm{~km} 2$ of the sea, and only $1,040 \mathrm{~km} 2$ of land area. Previous research conducted by Simbolon and Halim (2005) states that skipjack catches tend to be high at low SST.The sieveyield of each diameter was dried by means of a driven, and each diameter was measured by weight with an analytical scale, the remaining sieving results in the sludge were accommodated in a residual pan and by the pipette method. Based on the diameter of the grains and the weight percentage of the substrate components are clay depth (diameter $\varangle 0.004 \mathrm{~mm}$ ), mud (diameter $0.004-0.063$ ), sand (diameter $0.063-2.00 \mathrm{~mm}$ ) and gravel $(2-8 \mathrm{~mm})$. 


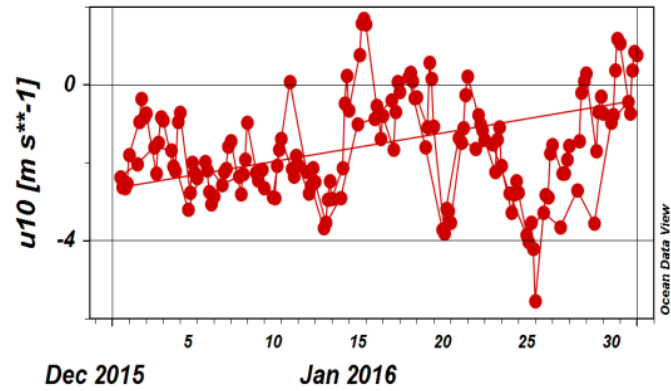

(a)

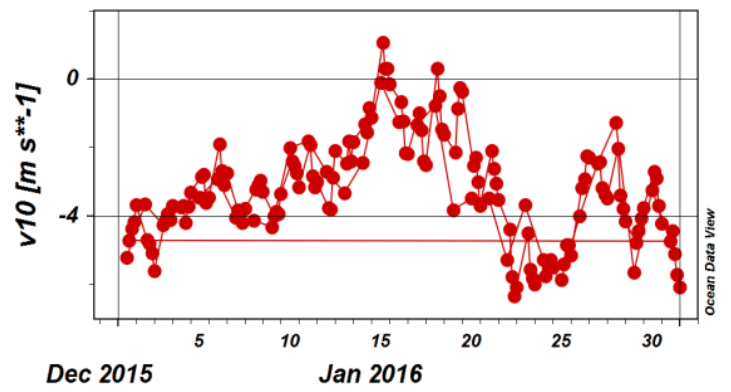

(b)

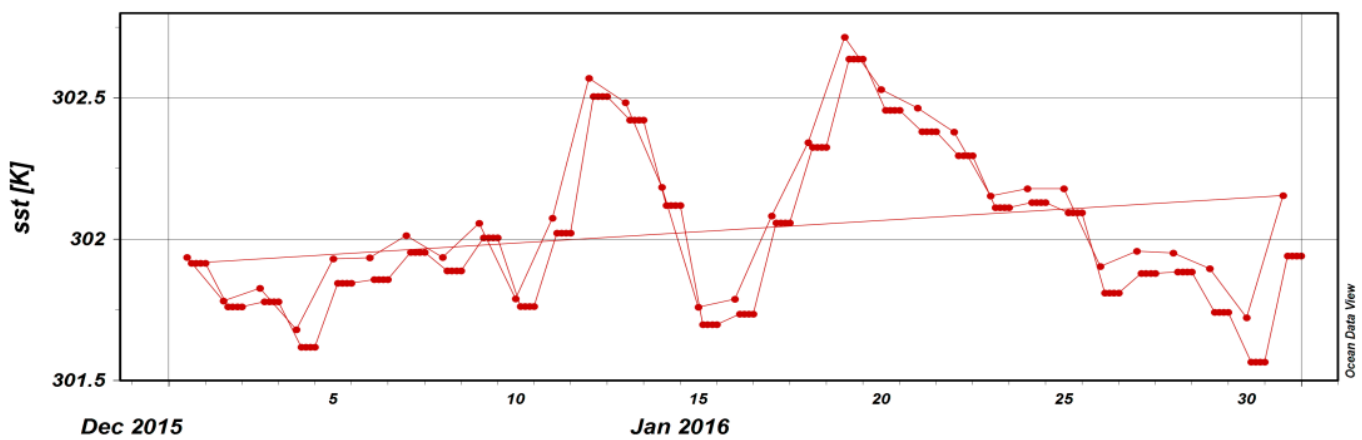

(c)

sst [K]@ time [hours since 1900-01-01 00:00:0.0]=first

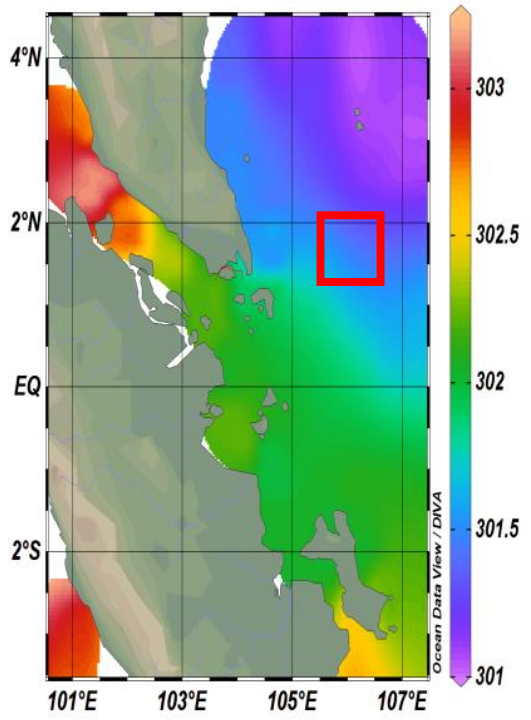

(d)

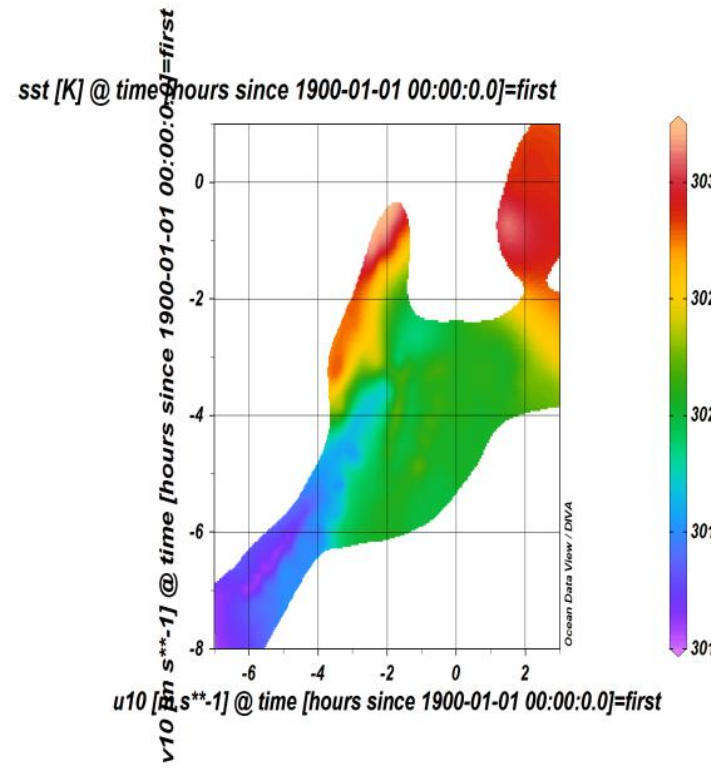

(e)

Fig. 3. (a) Component Speed U, (b) Component Velocity V, (c) Graph of sea surface temperature in Batam waters, (d) Sea surface temperature distribution, (e) Component velocity $\mathrm{U}$ and $\mathrm{V}$ with Sea surface temperature month January 


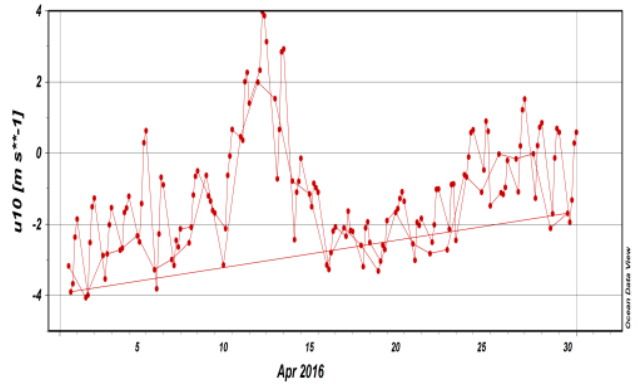

(a)

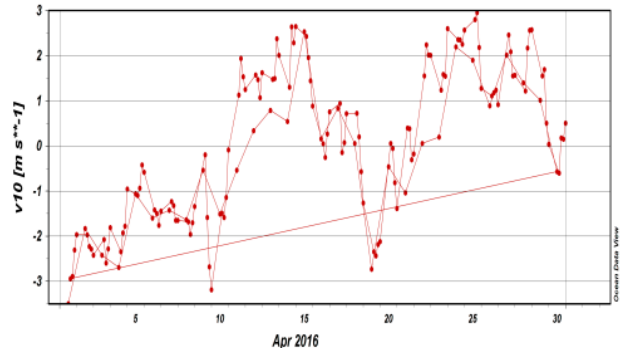

(b)

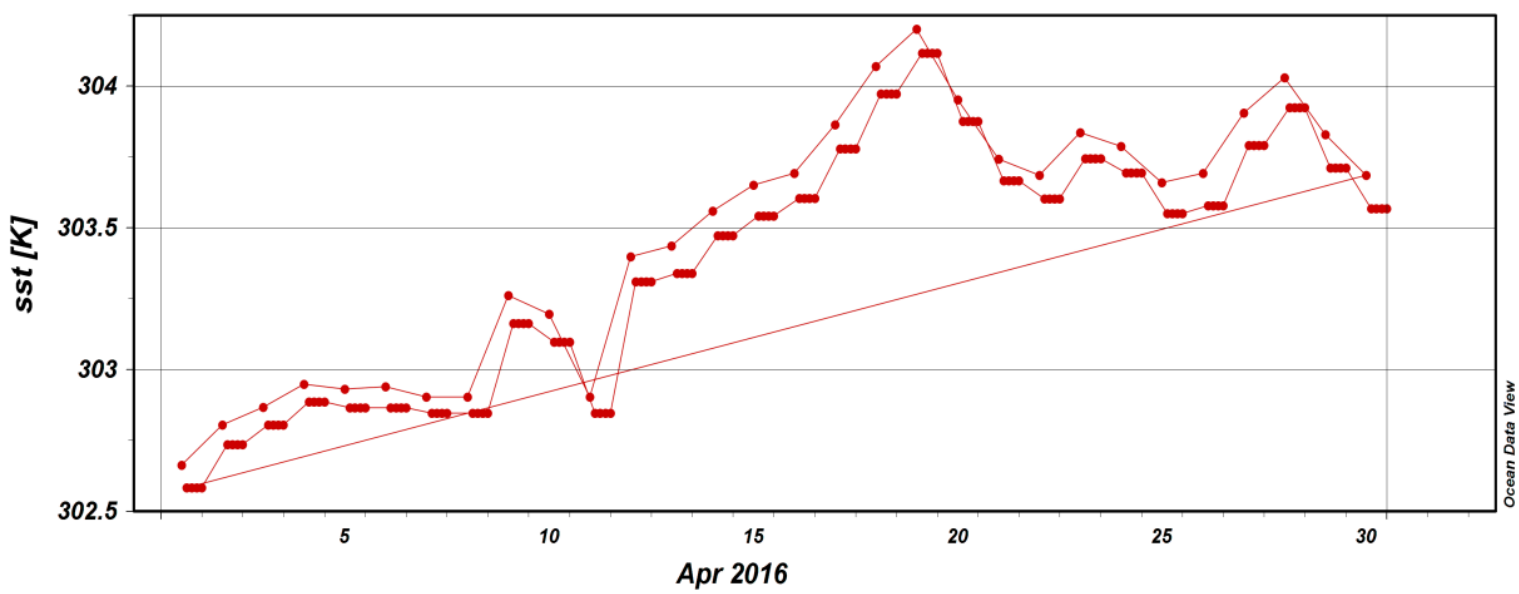

(c)

sst [K] @ time [hours since 1900-01-01 00:00:0.0]=first

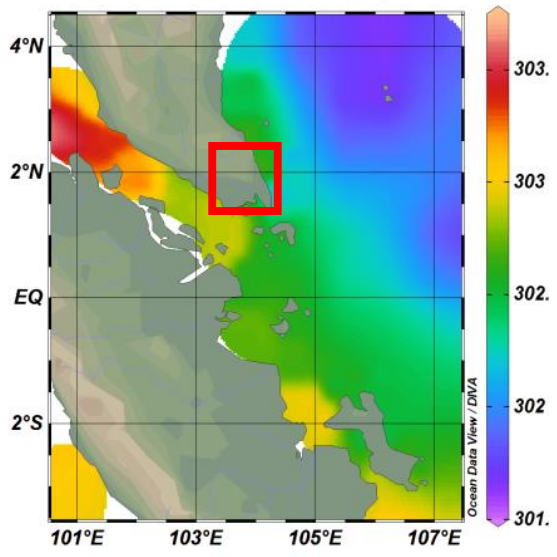

(d)

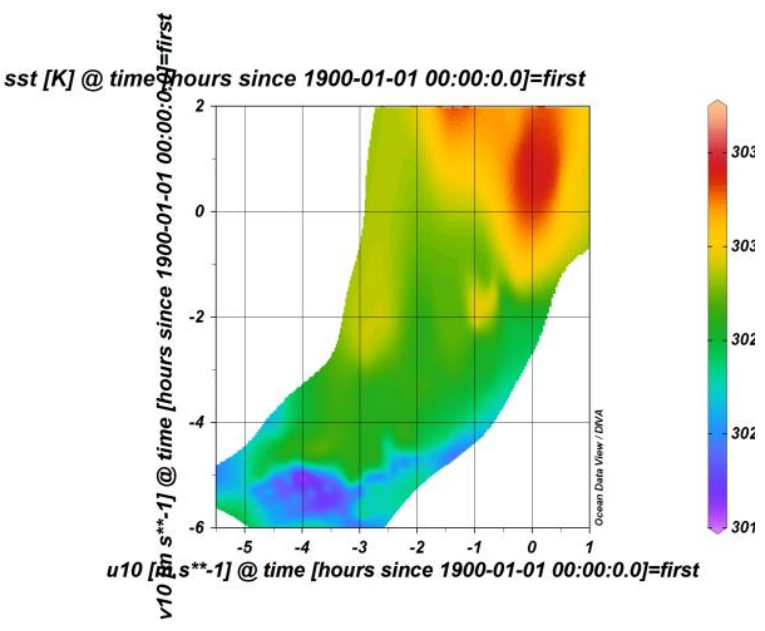

(e)

Fig. 4.(a) Component Speed U, (b) Component velocity V, (c) Graph of sea surface temperature in Batam waters, (d) Sea surface temperature distribution, (e) Component velocity U and V with Sea Surface temperature Transitions 1

The catch is high during the southwest monsoon and the beginning of the northeast monsoon. Sea levels, observations, satellite data, and observer stations of sea-level pressure and precipitation used to describethe evolution of sea surface temperature anomalies, surface wind velocity north and west, and rainfall patterns during the main periods in the east and middle for the tropical Pacific (Wang et al., 2017). To evaluate the cause of weather and climate change in Batam city, data on global climate change (ENSO) is needed, which will affect the Batam region

The circulation of seawater in Indonesian waters is influenced by the Monsoon wind system. Since the Monsoon wind system is constantly blowing, although relative speed is not great, it creates an excellent condition for the occurrence of a current pattern (Amri et al., 2013). In the western seasons, 
the current pattern of surface waters of Indonesia shows the current moving from the South China Sea to the Java Sea. The Java Sea, the current then moves into the Flores Sea until it reaches the Banda Sea, while at the time of the Southeast monsoon, the direction of the current completely reverses towards the west which eventually leads to the South China Sea (Utama et al., 2017; Surya et al., 2017).

The condition of the seasons in Indonesia is divided into 3 . This wind blows as the sun is in the southern hemisphere, which causes the continent of Australia is experiencing summer, resulting in minimum pressure and the continent of Asia is cooler, resulting in maximum pressure. The physical parameters of the sea in Batam can be seen in Fig. 3.

West monsoon winds that occur in January At coordinates $1^{\circ} 5^{\prime} 0$ " $\mathrm{N}, 104^{\circ} 2^{\prime} 0^{\prime}$ " E looks the highest wind speed with a value of $4.5 \mathrm{MS} * *{ }^{-1}$ For component $\mathrm{U}$. Component $\mathrm{V}$ has the highest value $5.2 \mathrm{MS}^{* *}{ }^{-1}$. The highest Batam sea temperature
(SST) in January occurred on 19-01-2016 with a value of $302,8^{\circ} \mathrm{K}\left(29.65^{\circ} \mathrm{C}\right)$. The transitional season 1 is the turn of the west monsoon to the east monsoon (Fig. 4).Transition season 1 which occurs in April At coordinates $1^{\circ} 5$ ' 0 " $\mathrm{N}, 104^{\circ} 2^{\prime} 0^{\prime \prime} \mathrm{E}$ shows the highest wind velocity seen with a value of 3.9 MS ** ${ }^{-1}$ For component U. As for component $\mathrm{V}$ has value Highest $-3.6 \mathrm{MS}^{* *-1}$. The highest sea surface temperature (SST) of Batam in April occurred on 1904-2016 with a value of $304.2^{\circ} \mathrm{K}\left(31.05^{\circ} \mathrm{C}\right)$. The east monsoon or southwest monsoon is the wind that blew in July-September in Indonesia. This wind blows when the sun is in the northern hemisphere. The Asian continent receives more heat than the sun so that the Asian continent is the area of minimum pressure (Fig. 5). Southeast monsoon winds that blow in the SMS area become the factor that evokes an upwelling. The wind blowing will generate a water mass transport known as Ekman transport. Generally, upwelling phenomenon in the coastal area is formed by Ekman dynamic process in the surface layer.

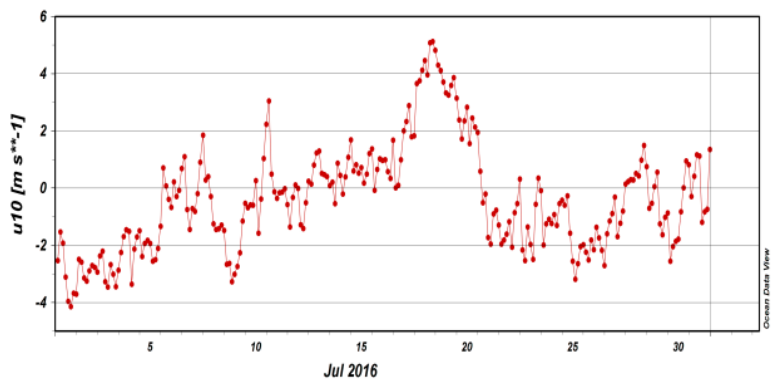

(a)

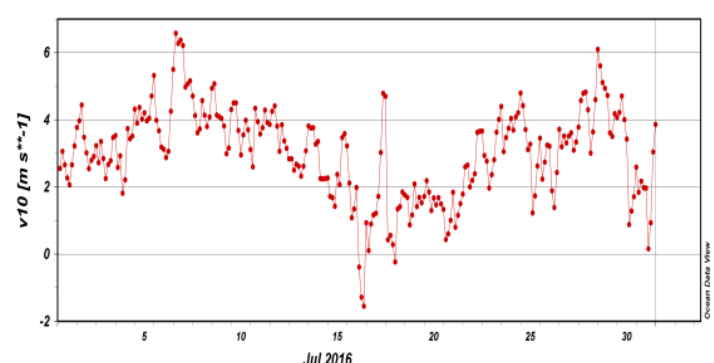

(b)

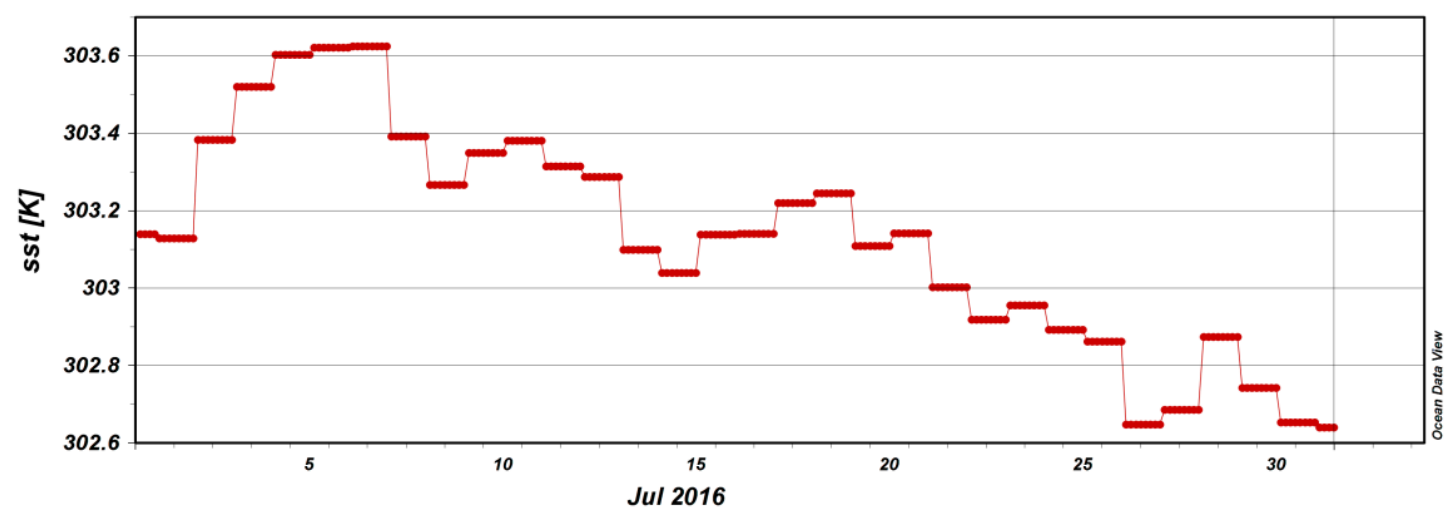

(c)

Fig. 5. (a) Component Velocity U, (b) Component velocity V, (c) Graph of sea surface temperature in Batam waters, (Cont.) 
sst [K] @ time [hours since 1900-01-01 00:00:0.0]=first

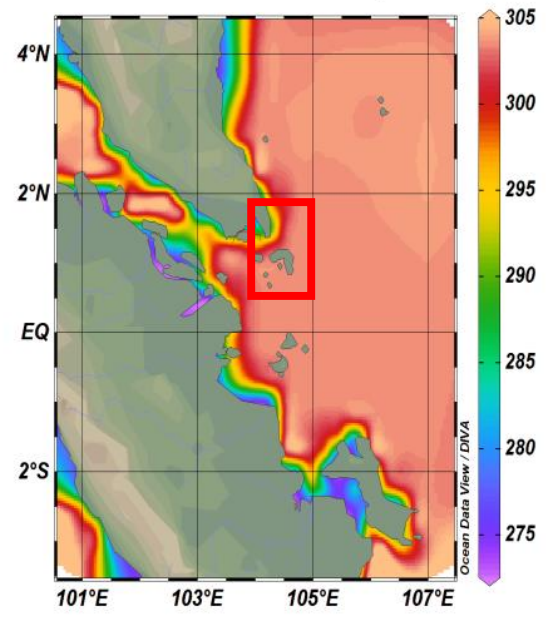

(d)

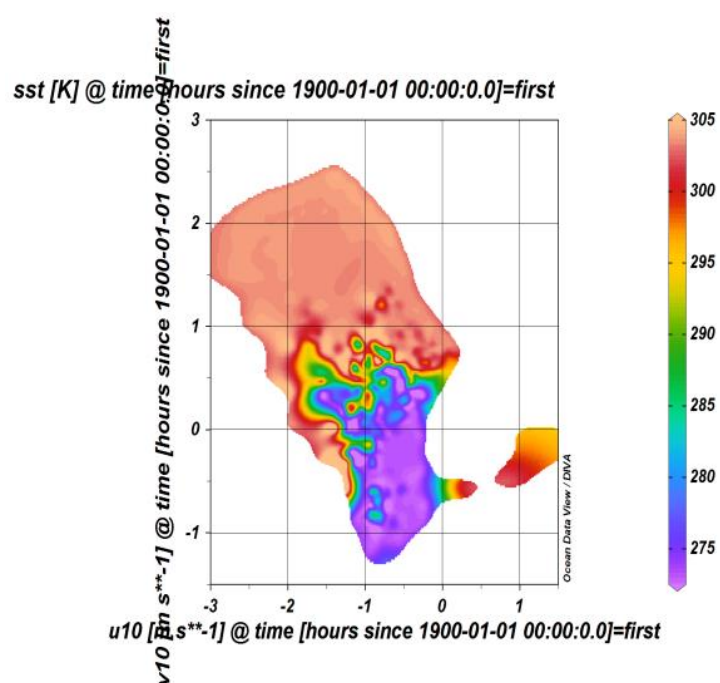

(e)

Fig. 5 (Cont.) (d) Sea surface temperature distribution, (e) velocity of $U$ and V Component component with Moon Sea Surface Temperature July.

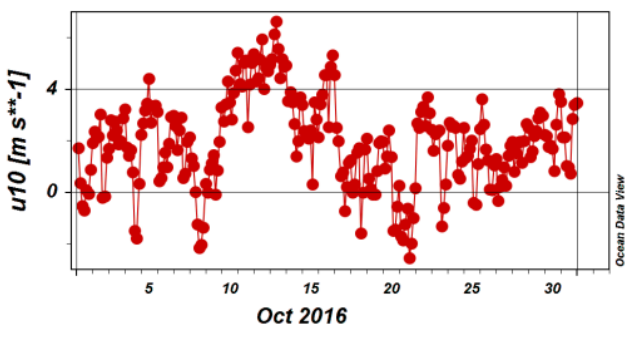

(a)

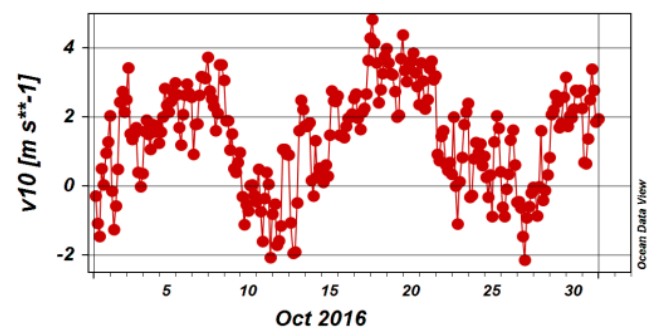

(b)

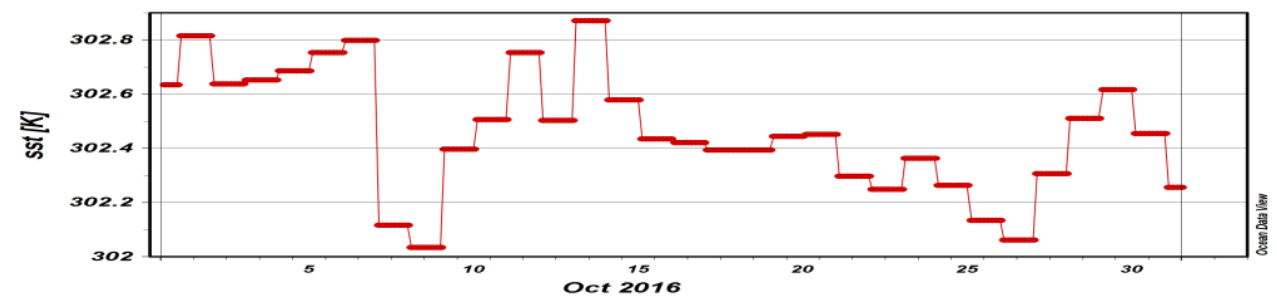

(c)

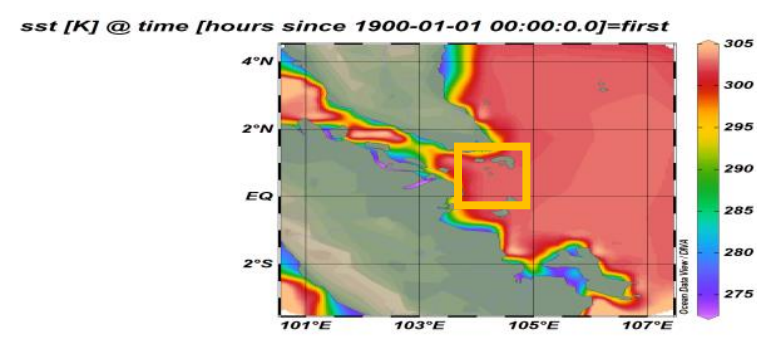

(d)

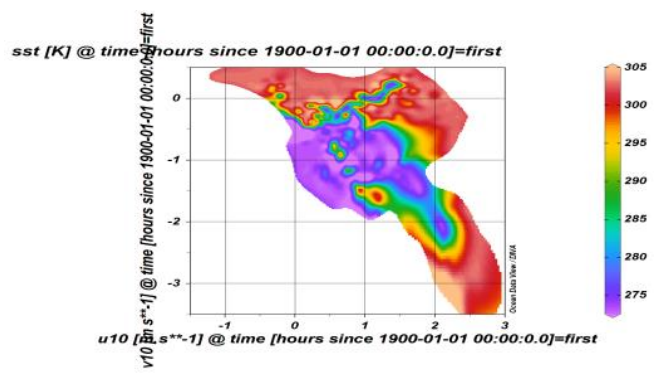

(e)

Fig. 6. (a) Component Velocity U, (b) Component velocity V, (c) Graph of sea surface temperature in Batam waters, (d) Sea surface temperature distribution, (e) velocity of $U$ and $V$ Component component with Sea Surface Temperature October 
July At coordinates $1^{\circ} 5$ ' 0 "N, $104^{\circ} 2$ ' 0 " E shows the highest wind velocity seen with a value of 5.05 MS **-1 For component U. As for component $V$ has value Highest $6.08 \mathrm{MS}^{* *^{-1}}$. The highest sea surface temperature (SST) of Batam in January occurred on 19-03-2016 with a value of $303.2^{\circ} \mathrm{K}\left(30.05^{\circ} \mathrm{C}\right)$. The transitional season 2 is the turn of the east monsoon to the west monsoon (Fig. 6).

The 2nd transition season occurs in October At coordinates $1^{\circ} 5^{\prime} 0$ " $\mathrm{N}, 104^{\circ} 2^{\prime} 0^{\prime \prime} \mathrm{E}$ shows the highest wind speed seen with a value of $6.6 \mathrm{MS}^{* *^{-1}}$ For component $\mathrm{U}$. As for component, $\mathrm{V}$ Has the highest score of $4.85 \mathrm{MS}^{* *}{ }^{-1}$. The highest Batam sea temperature (SST) in January occurred on 19-032016 with a value of $302.87^{\circ} \mathrm{K}\left(29.72^{\circ} \mathrm{C}\right)$. The exposure of heat as a process of shifting from the sea to the atmosphere gives rise to cooling of the ocean surface, which is proportional to the amount of evaporation. The rate of evaporation as the transfer of heat from the ocean to the atmosphere is an average of $1 \mathrm{~m} /$ year or about $3 \mathrm{~mm} /$ day (Ashok, 2001).

The result (Fig. 7) above shows that the identical $\mathrm{U}$ component is more normal to change the wind direction and its speed in comparison with component $\mathrm{V}$. The $\mathrm{U}$ component has the highest value in December worth $5.26 \mathrm{MS} * *{ }^{-1}$ with a positive value which means that the wind moves in the direction West. And for component $\mathrm{V}$ maximum value existed in January with value reaching $10 \mathrm{MS}$ $*^{*}{ }^{-1}$ with a negative value which means the wind move eastward. Time Series Sea Surface Temperature (SST) can be seen in (Fig. 8).
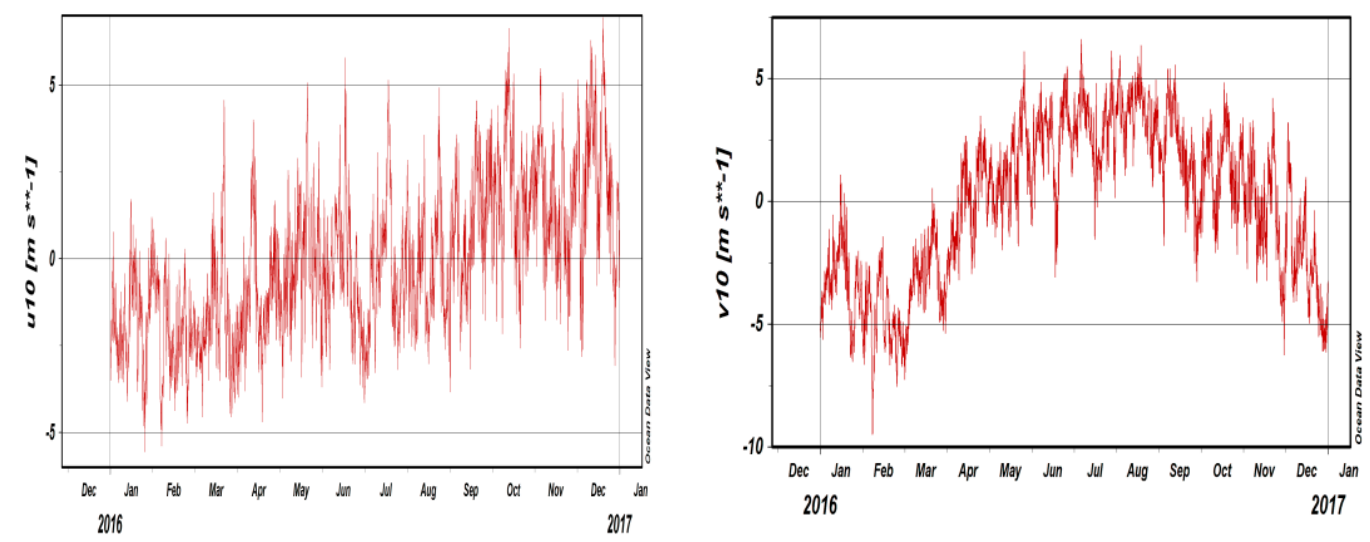

Fig. 7. Graph of component $U$, and $V$ annual period
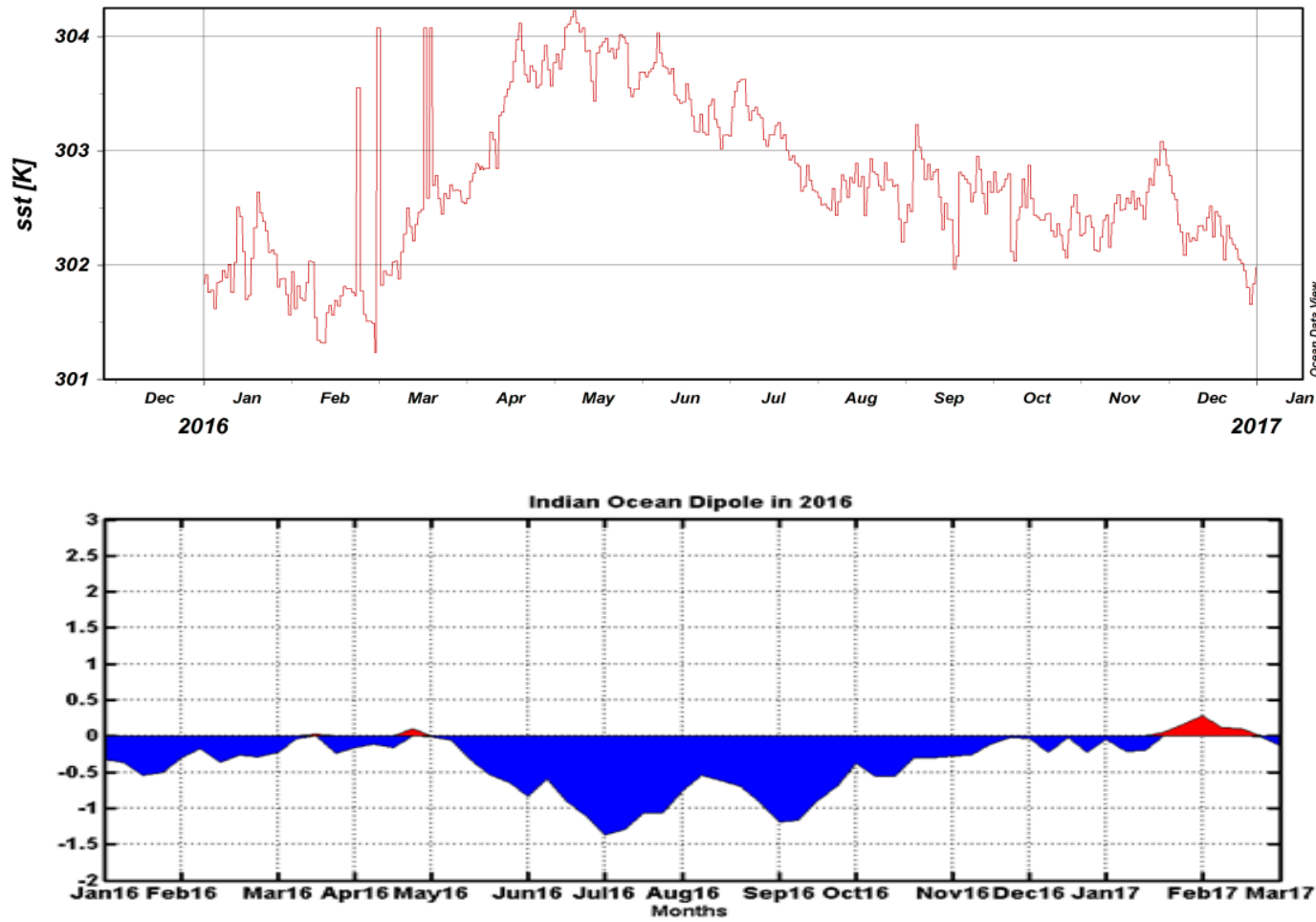
Fig. 8. Time Series Sea Surface Temperature (SST) Period and Indian Ocean Dipole Index in 2016

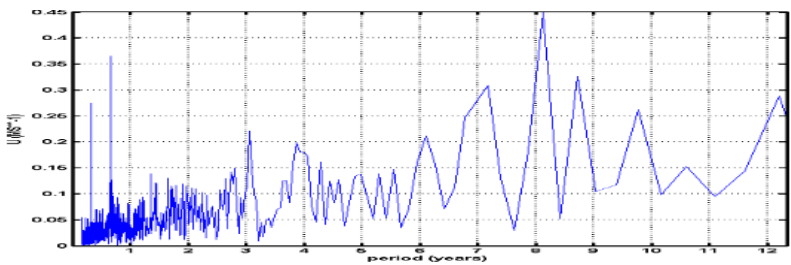

(a)

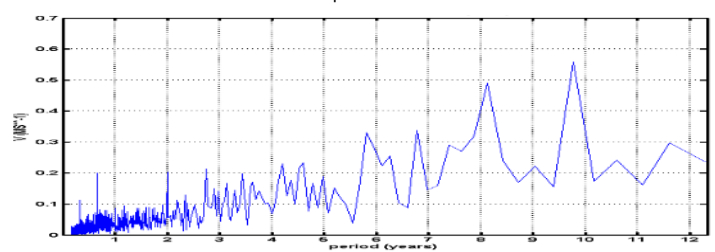

(b)

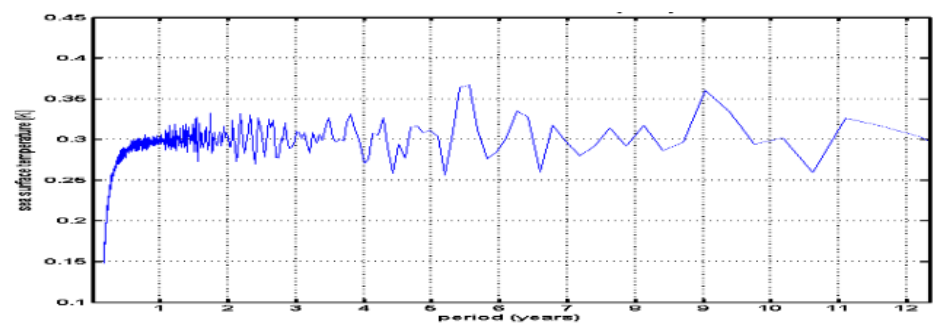

(c)

Fig. 9. Fast Fourier Transform (FFT) (a) Component U (MS **-1), (b) component V (MS ${ }^{* *-1}$ ) (c) Sea Surface Temperature (SST) in 2016

SST in Batam waters ( $1^{\circ} 5^{\prime} 0$ "N, $\left.104^{\circ} 2^{\prime} 0^{\prime \prime} \mathrm{E}\right)$ during annual period (Fig. 3-6). During the course of the west monsoon event, the waters of Batam (January-February) have sea surface temperature with low value. Significant changes occur during the transition season 1, sea surface temperature in the rock waters rises and falls randomly. The occurrence of east monsoon causes the sea surface temperature in the waters of Batam to rise in temperature, and at the time of the transition season, 2 sea surface temperatures around Batam experiencing the temperature drop is not so drastic. Indian Ocean where lower SST is usually found off the west coast of Sumatra and warmer SSTs exist in most of the western Indian Ocean. The mass of water coming out of West Sumatera intensively out in transition season I, only in 2005 seen flow twice season in one year that transition season I and transition season II. This is accompanied by Nieblas et al., (2014), that the current of South Java is the current passing through the western coast of Sumatra-South Java occurring semi-annually, with the strongest currents occurring during the transitional periods I and II.

In 2016, especially in June to November, moderate negative IOD is taking place with an index of -0.65 . At the same time, the SST in Batam waters is decreasing. This indicates that IOD negative can cause the decrease of SST in Batam. Fig. 9 shows the distribution of periods owned by the wind and SST velocities in Batam waters by 2016. The wind speed in the waters of Batam has a predominant period of 6 months (semiannual). However, the wind speed in the waters of Batam also has another period, namely intra-seasonal (35-90 days) and 10 monthly. Besides wind speed, SST in Batam waters also has a semiannual dominant period. This indicates that seasonal factors are strongly influencing changes in SST and wind in the waters of Batam.

\section{Conclusion}

The results of this study concluded that the temperature and wind velocity characteristics associated with Indian Ocean Dipole (IOD) in Batam waters have low sea surface temperatures. The sea surface temperature is highest in the 1st transition and in the east monsoon season, whereas in the east monsoon season it decreases. Sea surface temperature is highest in April-May, and the lowest is in February-March. The $U$ component is highest in December with the West (+ positive, and for the highest $\mathrm{V}$ component in January with the South (negative) direction. Sea surface temperature conditions in the sea of Batam didn't change significantly.Based on FFT results, wind speed and SST in Batam waters have a dominant period of 6 months (semiannual).

\section{References}

Akhir, M.F., Daryabor, F., Husain, M.L., Tangang, F. and Qiao, F., 2015. Evidence of upwelling along Peninsular Malaysia during southwest monsoon. Open Journal of Marine Science, 5(03), p.273.

Amri, K., Manurung, D., Gaol, J.L. and Baskoro, M.S., 2013. Karakteristik Suhu Permukaan Laut dan Kejadian Upwelling Fase Indian Ocean Dipole Mode Positif di Barat Sumatera dan Selatan Jawa Barat. Jurnal Segara, 9(1), pp.23-35.

Gadgil, S., Vinayachandran, P.N., Francis, P.A. and Gadgil, S., 2004. Extremes of the Indian summer monsoon rainfall, ENSO and equatorial Indian Ocean oscillation. Geophysical Research Letters, 31(12).

Gaol, J.L. and D. Manurung, 2000. El Niño Southern Oscillation Impact on Sea Surface Temperature Derived from Satellite Imagery and its Relationships on Tuna Fishing Ground in the South Java seawaters. AARS. Conference in Taipeh.

Ginzburg, A., Kostianoy, A., \& Sheremet, N, 2008. Sea surface temperature variability. The Black Sea Environment, pp.255-275.

Kausarian, H., Sri Sumantyo, J.T., Kuze, H., Aminuddin, J. and Waqar, M.M., 2017. Analysis of Polarimetric Decomposition, Backscattering Coefficient, and 
Sample Properties for Identification and Layer Thickness Estimation of Silica Sand Distribution Using L-Band Synthetic Aperture Radar. Canadian Journal of Remote Sensing, 43(2), pp.95-108.

Kausarian, H., Sumantyo, J.T.S., Kuze, H., Karya, D. and Panggabean, G.F., 2016. Silica Sand Identification using ALOS PALSAR Full Polarimetry on The Northern Coastline of Rupat Island, Indonesia. International Journal on Advanced Science, Engineering and Information Technology, 6(5), pp.568-573.

Kausarian, H., Sumantyo, J. T. S., Kuze, H., Karya, D., \& Wiyono, S, 2016. The Origin And Distribution Of Silica Mineral On The Recent Surface Sediment Area, Northern Coastline Of Rupat Island, Indonesia. ARPN Journal of Engineering and Applied Sciences, 12(4). pp.980-989.

Koch-Larrouy, A., Madec, G., ludicone, D., Atmadipoera, A and Molcard, R., 2008. Physical processes contributing to the water mass transformation of the Indonesian Throughflow. Ocean Dynamics, 58(3-4), pp.275-288.

Kogan, F.N., 2000. Satellite-observed sensitivity of world land ecosystems to El Nino/La Nina. Remote Sensing of Environment, 74(3), pp.445-462.

Lubis, M.Z. and Si, M., 2016. Signal Processing for Power Spectral Density (PSD). Signal processing for marine acoustic and dolphin using matlab, Edition.

Manyilizu, M., Penven, P. and Reason, C.J.C., 2016. Annual cycle of the upper-ocean circulation and properties in the tropical western Indian Ocean. African Journal of Marine Science, 38(1), pp.81-99.

Mudelsee, M., 2014. Extreme Value Time Series. In Climate Time Series Analysis (pp. 217-267). Springer International Publishing.

Naylor, R. L., Falcon, W. P., Rochberg, D., \& Wada, N, 2001. Using El Nino/Southern Oscillation climate data to predict rice production in Indonesia. Climatic Change, 50(3), pp.255-265

Nieblas, A.E., Demarcq, H., Drushka, K., Sloyan, B. and Bonhommeau, S., 2014. Front variability and surface ocean features of the presumed southern bluefin tuna spawning grounds in the tropical southeast Indian Ocean. Deep Sea Research Part II: Topical Studies in Oceanography, 107, pp.64-76.

Sahu, N., Behera, S.K., Yamashiki, Y., Takara, K. and Yamagata, T., 2012. IOD and ENSO impacts on the extreme stream-flows of Citarum river in Indonesia. Climate dynamics, 39(7-8), pp.1673-1680.

Simbolon. D. dan A. Halim, 2005. Suhu Permukaan Laut dan Kaitannya dengan Hasil Tangkapan Ikan Cakalang dan Madidihang di Perairan Sumatera Barat. Buletin Pemanfaatan Sumberdaya Perairan. Institut Pertanian Bogor. Bogor.

Surya, G., Khoirunnisa, H., Lubis, M.Z, Anurogo, W., Hanafi, A., Rizky, F., Timbang, D., Situmorang, A.D. Guspriyanto, D., Ramadhan, W.R. and Mandala, G.F.T., 2017. Karakteristik Suhu Permukaan Laut dan Kecepatan Angin di Perairan Batam Hubungannya dengan Indian Ocean Dipole (IOD). Dinamika Maritim, 6(1), pp.1-6.

Utama, F.G., Atmadipoera, A.S., Purba, M., Sudjono, E.H and Zuraida, R., 2017, January. Analysis of upwelling event in Southern Makassar Strait. In IOP Conference Series: Earth and Environmental Science (Vol. 54, No. 1, p. 012085). IOP Publishing.

Wang, C., Deser, C., Yu, J.Y., DiNezio, P. and Clement, A., 2017. El Niño and Southern Oscillation (ENSO): A review. In Coral Reefs of the Eastern Tropical Pacific (pp. 85-106). Springer Netherlands.

Wulandari, P.D., Pujiyati, S., Hestirianoto, T. and Lubis, M.Z., 2016. Bioacoustic characteristic click sound and behaviour of male dolphins bottle nose (tursiops aduncus). J Fisheries Livest Prod, 4(160), p.2.

Yang, X.J., Bal eanu, D. and Machado, J.T., 2014. Application of the local fractional Fourier series to fractal signals. In Discontinuity and complexity in nonlinear physical systems (pp. 63-89). Springer International Publishing. 